Diabetologia, Suppl. to $9,309-310(1973)$

(C) by Springer-Verlag 1973

\title{
Insulinotropic Potency of Glipizide in Vitro
}

\author{
A. Herchuelz and W.J. Malaisse \\ Laboratory of Experimental Medicine, Brussels University, Brussels, Belgium \\ Received: April 5, 1973, and in revised form: June 14, 1973, accepted: June 14, 1973
}

Summary. Glipizide stimulates insulin release from incubated pieces of rat pancreatic tissue. The dose-action relationship is characterized by an $\mathbf{E D}_{50}$ of approximately $0.04 \mu \mathrm{M}$, comparable to that of glibenclamide or glisoxepide. Like other sulphonylureas, the insulinotropic action of glipizide over $60 \mathrm{~min}$ incubation is barely detectable in the absence of glucose, maximal at intermediate glucose concentrations $(1.0$ to $1.5 \mathrm{mg} / \mathrm{ml})$, and present but short-lived at a higher glucose level $(3.0 \mathrm{mg} / \mathrm{ml})$.

Key words: Insulinotropic potency, glipizide, insulin secretion, hypoglycaemic sulphonamide, oral antidiabetic substances, beta-cell, glibenclamide, glisoxepide, glycodiazin, gliclazide, tolbutamide.
Glipizide was recently proposed as a new hypoglycemic sulphonylurea [1]. The aim of the present note is to evaluate the insulinotropic potency of this compound, using a method for the measurement of insulin secretion by incubatẹd pieces of rat pancreatic tissue [6].

\section{Materials and Methods}

Small pieces of pancreatic tissue (approximately $8 \mathrm{mg}$ each), removed from fed rats, were incubated for 30 or $60 \mathrm{~min}$ at $37^{\circ} \mathrm{C}$ in groups of 4 pieces each in bicarbonate-buffered media $(2 \mathrm{ml})$ equilibrated against a mixture of $\mathrm{O}_{2}(95 \%)$ and $\mathrm{CO}_{2}(5 \%)$, and containing bovine albumin $(5 \mathrm{mg} / \mathrm{ml})$, guinea-pig anti-insulin serum (kindly donated by Dr. P.H. Wright, Indiana University, Indianapolis), and as required, glucose and glipizide (K-4024 or $\mathrm{N}$ - $\{4$-[ $\beta$-(5-methyl-pyrazine-2-carboxamido)-ethyl]-benzene - sulphonyl - N'- cyclohexyl urea; Pfizer, Brussels). The amount of insulin released into the medium was deduced from the partial neutralization of the insulin antibodies [6] and expressed as $\mu \mathrm{U}$ insulin secreted per mg of incubated tissue over the stated period of incubation. In all experiments, an equal number of determinations ( $n$ ) were performed in media containing glucose alone and in media containing both glucose and glipizide. The increments in insulin release attributable to glipizide ( $d f=2 n-2)$ after 30 or $60 \mathrm{~min}$ incubation were used to calculate the sulphonylurea-induced increments in secretion rate during each period of incubation.

\section{Results}

At a glucose concentration of $1.0 \mathrm{mg} / \mathrm{ml}$, the rate of insulin secretion was close to that found in the absence of glucose, and averaged $7.2 \pm 1.6 \mu \mathrm{U} / \mathrm{mg}$ per $60 \mathrm{~min}(n=36)$. As the glucose concentration was increased to 1.5 and $3.0 \mathrm{mg} / \mathrm{ml}$, the rate of insulin release increased to $20.7 \pm 3.0(n=48)$ and $60.8 \pm 4.5$ $(n=31) \mu \mathrm{U} / \mathrm{mg}$ per $60 \mathrm{~min}$ respectively. At a low glucose level $(1.0 \mathrm{mg} / \mathrm{ml})$, the dose-action relationship for the insulinotropic effect of glipizide was characterized by a threshold value at concentrations ranging between $10^{-6}$ and $10^{-5} \mathrm{mg} / \mathrm{ml}$, and a maximal effect in the range between $10^{-4}$ and $10^{-3} \mathrm{mg} / \mathrm{ml}$ (Table 1 and Fig. 1). When the insulinotropic action of glipizide

Table 1. Effect of glipizide upon insulin secretion by incubated pieces of rat pancreatic tissue. Mean values ( \pm S.E.M.) for the increment in insulin output due to glipizide, in excess of the corresponding control value for glucose-induced insulin release, are shown together with the number of individual observations (in parentheses) and the statistical significance of the observed increments (N.S.: not significant) The control rates of insulin secretion induced by glucose alone are given in the text

\begin{tabular}{lllll}
\hline $\begin{array}{l}\text { Experimental conditions } \\
\begin{array}{l}\text { Glucose } \\
(\mathrm{mg} / \mathrm{ml})\end{array}\end{array}$ & $\begin{array}{l}\text { Glipizide } \\
(\mathrm{mg} / \mathrm{ml})\end{array}$ & & \multicolumn{2}{c}{$\begin{array}{l}\text { Glipizide-induced increments } \\
\text { in insulin output }\end{array}$} \\
\cline { 1 - 2 } \cline { 5 - 6 }$(\mu \mathrm{U} / \mathrm{mg}$ per $60 \mathrm{~min})$ & $P$ \\
\hline 1.0 & $10^{-2}$ & $+7.1 \pm 3.8(32)$ & $<0.070$ \\
1.0 & $10^{-8}$ & $-2.8 \pm 2.4(18)$ & N.S. \\
1.0 & $10^{-7}$ & $-1.4 \pm 2.5(18)$ & N.S. \\
1.0 & $10^{-6}$ & $+3.2 \pm 2.7(17)$ & N.S. \\
1.0 & $10^{-5}$ & $+6.4 \pm 2.7(35)$ & $<0.025$ \\
1.0 & $10^{-4}$ & $+13.7 \pm 3.0(18)$ & $<0.001$ \\
1.0 & $10^{-3}$ & $+16.1 \pm 3.2(18)$ & $<0.001$ \\
\hline 1.5 & $10^{-2}$ & $+17.5 \pm 3.3(18)$ & $<0.001$ \\
\hline 3.0 & $10^{-2}$ & $+29.6 \pm 4.2(48)$ & $<0.001$ \\
\hline
\end{tabular}

$\left(10^{-2} \mathrm{mg} / \mathrm{ml}\right)$ was tested at various glucose concentrations (Table 1), the increments in insulin output attributable to the drug were of doubtful significance in the absence of glucose and at high glucose concentration $(3.0 \mathrm{mg} / \mathrm{ml})$ but quite obvious at intermediate glucose levels $(1.0$ and $1.5 \mathrm{mg} / \mathrm{ml})$. The failure of glipizide to cause a significant increase in insulin release at high glucose concentration (Table 1, last line is 
only apparent). Indeed, the increment in secretion rate induced by glipizide was much more marked. when estimated over a shorter period of incubation $(30 \mathrm{~min})$. Thus, in this initial period $(0$ to $30 \mathrm{~min})$, glipizide provoked a significant increase in insulin output $(+9.7 \pm 4.1 \mu \mathrm{U} / \mathrm{mg} / 30 \mathrm{~min} ; n=30 ; p<$ 0.025 ) in excess of that evoked by glucose alone $(3.0 \mathrm{mg} / \mathrm{ml})$, whereas no further effect of the sulphonylurea $(-0.2 \mu \mathrm{U} / \mathrm{mg} / 30 \mathrm{~min}$ ) could be detected during the second period of incubation (30 to $60 \mathrm{~min}$ ).

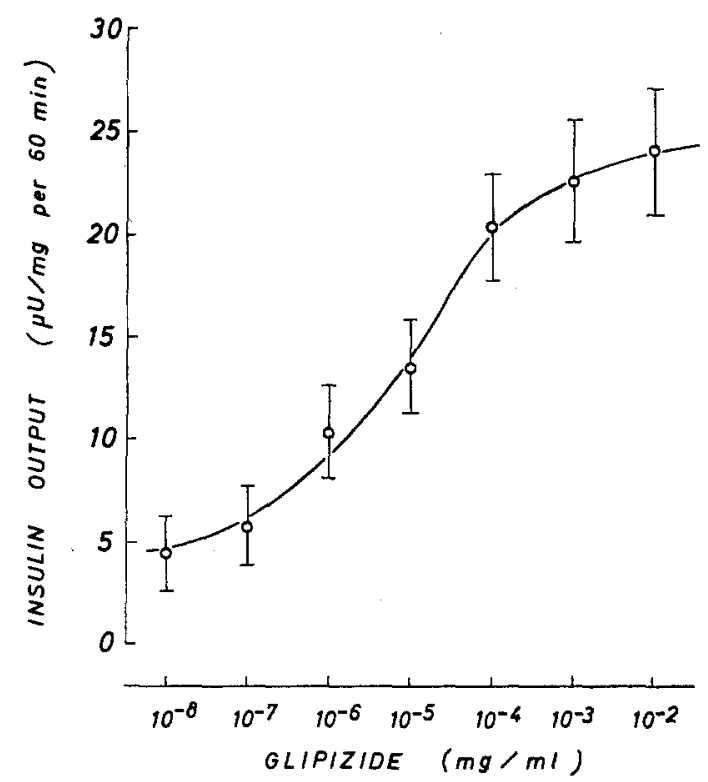

Fig. 1. Mean values ( \pm S.E.M.) for insulin output induced by glipizide in the presence of glucose $(1.0 \mathrm{mg} / \mathrm{ml})$

\section{Discussion}

The data illustrated in Table 1 and Fig. 1 indicate that glipizide is a potent insulinotropic sulphonylurea. As previously observed with glibenclamide or glisoxepide $[2,4]$, the minimal effective dose of glipizide ranges between $10^{-6}$ and $10^{-5} \mathrm{mg} / \mathrm{ml}$; and maximal insulinotropic action is achieved at concentrations of $10^{-4}$ to $10^{-3} \mathrm{mg} / \mathrm{ml}$. Between these concentrations, the $\mathrm{ED}_{50}$ was calculated from the regression of the increments in insulin secretion rate on the logarithmic values for glipizide concentration. The $\mathrm{ED}_{50}$ for the insulinotropic action of this compound approximated $18 \mathrm{ng} / \mathrm{ml}$ or $0.04 \mu \mathrm{M}$, a value comparable to that previously found with this technique for glibenclamide and glisoxepide and much lower than that observed for gliclazide or glycodiazin [3]. The modulation of the insulinotropic action of glipizide by the glucose concen. tration of the incubation medium (Table 1) is similar to that reported for other hypoglycemic sulphonylureas and sulfonamides $[2,3,4,5]$. In all cases, the insulinotropic effect is small and occasionally insignificant in the absence of glucose, and reaches its maximal value at glucose concentrations of 1.0 or $1.5 \mathrm{mg} / \mathrm{ml}$. Our data also indicate that the insulinotropic action of glipizide, like that of tolbutamide, glycodiazin and glisoxepide $[2,4,5]$, fades out rather rapidly at a high glucose concentration $(3.0 \mathrm{mg} / \mathrm{ml})$. These converging findings support the concept that the sulphonylureas have a common mode and site of action in the pancreatic beta cell, despite the widely variable concentrations at which a dose-action relationship is observed.

Acknowledgements. This work was supported in part by a grant from the F.R.S.M. (Brussels), the association contract Euratom-Universities of Brussels and Pisa, and a grant-in-aid from Pfizer Europe (Brussels).

\section{References}

1. Ambrogi, V., Bloch, K., Daturi, S., Griggi, P., Logemann, W., Mandelli, V., Parenti, M.A., Rabini, T., Usardi, M. M., Tommasini, R.: Pharmacological study on a new oral antidiabetic: N-(4-[ $\beta$-(5-methyl-pyrazine2-carboxamido) - ethyl] - benzene - sulphonyl) - N' - cyclo hexyl-urea or K 4024. Arzneimittel-Frorsch. 21, 208-213 (1971)

2. Brisson, G.R., Malaisse, W.J.: Insulinotropic effect and possible mode of action of a new potent sulfonylurea (BS-4231). Canad. J. Physiol. Pharmacol. 49, 536-544 (1971)

3. Malaisse, W.J., Leclercq-Meyer, V.: Insulinotropic action of a now sulfonylurea: gliclazide. Rev. europ. étud. clin. biol. 17, 310-314 (1972)

4. Malaisse, W.J., Malaisse-Lagae, F.: Effects of glycodiazin and glybenclamide upon insulin secretion in vitro. Europ. J. Pharmacol. 9, 93-98 (1970)

5. Malaisse, W.J., Malaisse-Lagae, F., Mayhew, D.A., Wright, P.H.: Effects of sulfonylureas upon insulin secretion by the rat's pancreais. Excerpta Med. Found. ICS 149, 49-60 (1967)

6. Malaisse, W., Malaisse-Lagae, F., Wright, P.H. : A now method for the measurement in vitro of pancreatic insulin secretion. Endocrinology 80, 99-108 (1967)

Dr. W.J. Malaisse

Laboratoire de Médecine Expérimentale Boulevard de Waterloo, 115

B-1000 Bruxelles

Belgium 